\title{
TRIANON ÉS A BRIT FÖLDRAJZ II.
}

\author{
GYŐRI RÓBERT - CHARLES W. J. WITHERS \\ BRITISH GEOGRAPHY AND THE TRIANON PEACE TREATY (PART 2)
}

\begin{abstract}
The effect of the Treaty of Trianon (1920) upon Hungary's boundaries is well understood. Surprisingly, however, almost no attention has been paid to the work of the various national geographical delegations which helped advise politicians as the boundaries of Europe were re-cast after World War I. This paper examines the work of the British geographical delegation in Paris as it advised upon Trianon. Particular attention is paid to the work of Alan Ogilvie, and to Ogilvie's relationships with Isaiah Bowman, effective head of the American delegation. The paper examines Ogilvie's diaries and correspondence to provide detailed insight into how ethnic identity, linguistic difference and other criteria were used (or not) to define and map the new Hungary and the new Europe. The paper shows how questions to do with the complexity of Hungary's ethnic diversity were known to British geographers and map makers as early as 1915. It shows, too, that no single view was held over how to map boundaries: some British geographers favoured delimitation based upon physiographic divides, such as river and drainage basins. Others favoured ethnic difference based on use of the mother tongue. For yet others, attention was paid to lines of communication and to economic market area. Because such differences were apparent in the British geographical community during World War One, notably between prominent members of the Royal Geographical Society, British geographers offered no consistent view upon Hungary's delimitation and 'dismemberment' following Trianon. British geographers turned to the meetings of the British Association for the Advancement of Science in order to debate these differences and to review Hungary's position in the new Europe after 1920.
\end{abstract}

Keywords: Hungary; Treaty of Trianon; World War I; British geography

\section{Bevezetés}

Tanulmányunk első részében felvázoltuk, hogyan kapcsolódtak be a különböző nemzeteket képviselő geográfusok az első világháborút lezáró békekötések előkészítő munkáiba, hogyan próbálták meg a meglévő szakmai kapcsolatrendszerület saját országuk ügye mellett mozgósítani. Bemutattuk a Magyarország területi épségének védelmében kifejlesztett magyar földrajzi érvrendszert és két, a háború után megjelent összefoglaló földrajzi kötet elemzésével az új határokról kialakított brit véleményeket. Tanulmányunk második részében rekonstruáljuk a brit földrajzosok Magyarországgal kapcsolatos véleményét a Trianon előtti időszakból, illetve részletesen ismertetjük a brit delegáció párizsi munkáját. Feltárjuk OGILVIE párizsi tevékenységét és a határok térképezésében szerzett korábbi tapasztalatait, a közös munkáját a cambridge-i történésszel, a brit delegáció tagjával, HAROLD TEMPERLEYvel, aki a párizsi konferencia részletes értékelését megírta (TEMPERLEY, H. 1920), és aki OGILVIE-t az 1922-es könyvének elkészítésére felkérte. Ebben az időben nyújtotta be OGILVIE egy új brit földrajzi szervezetre vonatkozó javaslatát is, amelyben a brit kormányzati szervek és térképezési munkák kapcsolatát, valamint a határvidékek térképezének különböző megoldásait taglalta. Írásunk végén visszatérünk NEWBIGIN, MCFARLANE és mások előadásaihoz, tanulmányaihoz, valamint megvilágítjuk, hogy miért a Brit Tudományos Társaság (British Association for the Advancement of Science - BAAS) E szekciója és nem pedig a Brit Királyi Földrajzi Társaság (Royal Geographical Society - RGS) biztosított fórumot a brit földrajzosoknak Magyarország és Trianon ügyének megvitatására 1920 után. 
Elemzésünk során a fó törekvésünk az volt, hogy dokumentáljuk mindazt, amit a brit geográfusok Trianon földrajzi következményeiről és az új Európáról írtak vagy mondtak. Természetesen nem csak az elhangzottak rögzítése volt a célunk, hanem azt is megpróbáltuk megérteni, hogy ki mondta, miért mondta, hogyan, milyen körülmények között fogalmazta meg az állításait, ezért arra törekedtünk, hogy a források „mögé” is benézzünk. Fontos tudatosítani, hogy az elemzett szövegek eltérô közegben fogantak: többségüket pályájuk elején állók írták, különböző intézményekben keletkeztek, és magánlevelezésben, nyilvános beszédekben vagy nyomtatásban öltöttek testet. Célunk volt az is, hogy jobban megvilágítsuk a földrajzosok munkája és a saját életútjuk közti kapcsolatokat.

\section{Szakértői munka a béketárgyalásokon: Alan Ogilvie és brit geográfusok Párizsban és Londonban}

ARTHUR HinKs 1920 áprilisában a párizsi békekonferenciáról szóló beszámolóját így kezdte: „Amikor majd a történelemtudomány foglalkozni kezd a békeszerzódésekkel, azt is vizsgálni fogja, hogy mennyire követte a földrajzi elveket a párizsi kongresszus. Ezért érdemes most kitérnünk arra, hogy milyen mélységben álltak a szövetséges és társult hatalmak rendelkezésére a megalapozott földrajzi információk a tárgyalások elókészitésénél és a határozatok meghozatalakor" (n. n. 1920, p. 309).

HiNks szerint a területi döntéseket négy egymásra épülő eljárás során alakították ki. Elsőként „,döntés született arról, hogy milyen legyen nagy vonalakban a politikai felosztás, majd igyekeztek megkeresni minden egyes esetben a lehetó legjobb határt. Ezt követte az új határok szabatos kijelölése, majd a határmegállapító bizottságok a helyszínen kitüzték a határvonalakat.” Bár ezek közül „többé-kevésbé mindegyiknek voltak földrajzi vonatkozásai”, és különösen az első volt a „legszélesebb értelemben vett földrajzi kérdés”, HINKS kételkedett abban, hogy ,a földrajzosok véleményét nagy súllyal vették volna figyelembe a legfontosabb döntéseknél" (n. n. 1920, p. 310). Ugyanígy bizonytalan volt abban is, hogy a harmadik és a negyedik fázisba bevonták-e a geográfusokat. Ezzel ellentétben a második szakasz, ,, a legjobb határ megkeresése ... többféle földrajzi tudást is megkövetelt”. Ehhez ugyanis szükség volt „a nagy méretarányú térképek szakszerü használatára, ... arra az ismeretre, hogy a helyszínen milyen állandó határvonalat lehet majd könynyen kitüzni, ... és arra a képességre, hogy azt a határt találják meg, amely a különbözó térségek gazdasági életét a lehető legkevésbé befolyásolja” (n. n. 1920, p. 310). A különbözô brit kormányhivatalok kiterjedt hírszerző tevékenységének ellenére HinKs óvatosan fogalmazott a béketárgyalások előtt elvégzett földrajzi munka kapcsán: „kétséges, hogy a brit delegációnak rendelkezésére álltak volna az elókészített anyagok a fegyverletétel idején" (n. n. 1920, p. 310).

Hinks beszámolójában elkülönítette a Párizsban végzett földrajzi munkát a béketárgyalások megkezdése előtti földrajzi munkától. A kettő persze nem volt ilyen egyszerúen elválasztható egymástól. A brit geográfusok szakértői munkájuk során többször megjárták a Párizs és London közötti utat, folyamatos volt a kapcsolattartás az RGS és a Párizsban dolgozó földrajzosok között. OGILVIE felesége volt a legfontosabb összekötő, de maga OGILVIE is sokat utazott, HedLEY viszont nem hagyta el Londont. (Keveset tudunk WYNNE őrnagy tevékenységéról, és nincsenek információk PARKER kapitány munkájáról, aki OGILVIE-t helyettesítette 1919 augusztusától.) OGILVIE szerepvállalását a korábban megszerzett tapasztalatai magyarázzák. Ugyanakkor OGILVIE-t a szakértői munkában való részvétele (Párizsban és Londonban egyaránt), a különböző delegációk közti összekötő feladatai 1919-re már kiemelték oot a brit földrajzosok közül, és azt is megmutatták, hogy 
a brit földrajz egésze hiányosságokkal küzdött. A brit geográfusok nem csak a magyarországi nemzetiségi viszonyok térképezésénél ütköztek nehézségekbe, hanem már korábban is, amikor a magyaroknak a többi nemzetiség feletti dominanciáját kész tényként kezelték.

\section{A brit földrajz Magyarország-képe Trianon elött}

A brit földrajzosok már évekkel azelőtt szembesültek a magyarországi nemzetiségek térképezésének nehézségeivel, mielőtt Teleki és munkatársai megalkották volna a Carte rouge-t, és még azelőtt, hogy a háború befejeződött volna. Ennek első számú bizonyítéka az az előadás, amit az RGS-ben 1915 novemberében tartottak. HINKS javaslatára BERTIE COTTERRELL WALLIS földrajztanár mutatott be egy részletes elemzést Magyarország térképezésének azokról a kérdéseirôl, amelyek az RGS által gondozott, 1:1 milliós Európatérkép megalkotása során merültek fel. WALLIS a statisztikai szemlélet és a statisztikára épülő ábrázolási módszerek térképészeti és földrajzi használatának népszerúsítőjeként vált ismertté (WALLIS, B. 1911). Rögtön tanulmánya elején megállapította: „A térképész számára minden bizonnyal Magyarország jelenti majd a legnagyobb nehézséget, hiszen nem kevesebb mint hét nemzetiség él magyar uralom alatt" (WALLIS, B. 1916, p. 177). WALLIS tanulmánya leginkább egy összehasonlító térképtani elemzés volt. Telekihez hasonlóan az 1910-es népszámlálás adatait használta, és különböző térkép-típusokat készített (népsűrüségi, területi, izovonalas, izoplet, choroplet stb. térképeket), hogy bemutassa a nyelvhasználatra épülő nemzetiségi térképezés nehézségeit. De ennél lényegesebb az a következtetés, amire a térképek készítése során jutott. A térképek legfontosabb tanulságát WALLIS a magyar dominanciában és a többi nyelvi-nemzetiségi csoport elnyomásában látta: „A magyar kultúrát nem békés úton terjesztik" (WALLis, B. 1916, p. 185).

Az előadást követő vita hozzászólói elismerően fogadták WALLIS innovatív térképészeti megoldásait, annak ellenére, hogy az elóadó nem titkolta, folyamatban lévő kutatásról van szó. (WALLIS már az 1915-ös BAAS konferencián is bemutatta a munkáját, így HiNKS már nem első ízben hallott az eredményekről). A hozzászólók között volt a legtekintélyesebb brit gazdaságföldrajzos, LIONEL LYDE a University College London professzora. LYDE ismerte WALLISt, és maga is a statisztikai módszerek híve és népszerűsítője volt egyetemi előadásain. Nem értett egyet viszont WALLISnak azzal a meglátásával, hogy az országhatárokat nemzetiségi határokhoz kellene igazítani: „Én abban hiszek, hogy a folyó a legjobb politikai határ, és Önnek is a folyók mentén kell meghúznia a javasolt határokat" (LYDE, L. et al. 1916, p. 188). LYDE-nak ez a véleménye, hogy természetföldrajzi és nem a társadalomföldrajzi jelenségekhez kell igazítani a határokat, összhangban volt a korábbi katonai földrajzi munkáival (LYDE, L.-MocKLER-FERRYMAN, A. F. 1905). (LYDE a földrajz és a térképezés háborús idôkben való fontosságát hangsúlyozta ez idő tájt [HoLDICH, T.-LydE, L. 1915; BELLOC, H. 1915]). Hasonló állásponton volt a jövő Európájának határait illetôen is (LYDE, L. 1915). Így írt erről Some Frontiers of To-morrow c. munkájában: „minden másnak a kulcsa Magyarországon van, ahol az ország természetföldrajzi alapja nagyon egyszerü, de a politikai ügyek bonyolultak" (LYDE, L. 1915, p. 82). A természetes határok kitüntetett szerepéről vallott nézetét Nagy-Britannia határkérdésekben első számú szaktekintélye is osztotta.

THOMAS HoLDICH egész munkásságát a természetes határokon nyugvó politikai határok térképezésének szentelte (Afganisztánban, Beludzsisztánban, az Andok Kordilleráiban), és nyugdíjba vonulva írta meg az élettapasztalatait a háború alatt. A Political Frontiers and Boundary Making (1916) c. könyve ezeknek az írásoknak a sorába illeszkedik. Másokhoz hasonlóan HoLDICH is a háborúba süllyedt Európáról és az elkövetkező béke lehetôségérôl írt. Azon az állásponton volt, hogy két alapvető feltételt kell teljesítenie a „tudomá- 
nyos alapon megvont nemzetközi határnak.” „Mindenekelött elválasztó szerepe legyen a határnak, másrészt olyan elhelyezkedésü legyen, ami az ott élö emberek akaratának is megfelel" (Holdich, T. 1916, p. 286). A határok HoLDICH számára természeti elemeket: hegygerinceket vagy katonailag védhető topográfiai elemeket jelentettek: „Védhetôség, azaz napjainkban elösorban a tüzérségi fölény megteremtése, ez a legfontosabb" (HoLDICH, T. 1916 , p. 288). Ez mindenképpen igaz is volt a 20. század elején, mielőtt a repülőgépek bevetése örökre megváltoztatta volna a hadviselést. „Csak kevés tudományos alapon nyugvó határt találunk Európában" (HoLDICH, T. 1916, p. 286), ami valóban megfelelt ezeknek az elveknek. Mintha a jövőbe látna, a keleti térségekben várható változásokat emelte ki: „Közép-Európában lesz a legnehezebb ezeknek az elveknek az érvényesítése. A nehézségek eredete azoknak a nemzetiségeknek az összekeveredésében rejlik, amelyek ellenálltak az asszimilációnak. ... Ez a keveredés a nagy területü országok földrajzi felépítésének köszönhetö: nincsenek olyan természeti földrajzi gátak, amelyek a többirányú népességmozgást megakadályozták volna.” (HoLDICH, T. 1916, p. 293). Lengyelország „, a legkomplexebb”, „Közép-Európa küzdötere, a területi viták legvalószínúbb helyszíne” (HoLDICH, T. 1916, p. 295). Magyarország sorsán azonban nem kell sokat töprengeni: „Magyarország egy olyan állam, ami nem érdemel szimpátiát: sem ellenségként a mostani háború idején, sem pedig békeidöben mint a kisebb nemzetiségek zsarnoka" (HOLDICH, T. 1916, p. 302).

Az RGS-en belül persze különböztek a vélemények a határok kialakítását illetően. HoLDICH egész életén keresztül hangoztatott nézete a hegygerincekről és a katonai védhetôségről (Magyarország számára ez nyilvánvalóan a Kárpátok határát jelentette volna), továbbá az a meglátása, miszerint itt a jövőbeli határmegvonás az etnikai kérdések miatt különösen nehézkes, csak egy volt a sok vélemény közül. A háború végén írt munkájában (ekkor már az RGS elnöke volt) HoLDICH fel is adta a természetes határokkal kirajzolódó magyar nemzetállam ideáját: ,,akárhol is húzódjanak majd az új határvonalak, nincs esély arra, hogy markáns természeti akadályokhoz legyenek kötve" (HoLDICH, T. 1918, p. 118). (A könyvröl KoguTOWICZ KÁROLY írt részletes kritikát a Földrajzi Közleményekben [1919].) LYDE továbbra is ragaszkodott a természetes határok elképzeléséhez (leginkább a folyóknál meghúzott határokhoz), de HoLDICH-nál kompromisszumkészebb volt. WALLIS és HinKS az etnikai elhatárolás mellett tette le a voksát. A párizsi tárgyalásokon már ez az elgondolás dominált.

Nem csak az RGS-ben, hanem az admiralitás tengerészeti hírszerzési osztályán (Naval Intelligence Department) is foglalkoztak Magyarország jövőjével. Itt a readingi University College földrajzprofesszora, HENRY DiCKSON irányította a földrajzi adatgyújtő, térképező munkát. A hadügy és a haditengerészet számára, majd a békekonferenciára összeállított, bizalmasan kezelt, titkosított elemzések, atlaszok, kézikönyvek készítésébe - másokkal együtt - Hinks, McFARlane, Rudmose BROWn és Wallis is bekapcsolódott. A Magyarországot, elsősorban a nemzetiségi viszonyokat bemutató, belső használatú atlasz szerkesztésében az oroszlánszerep minden bizonnyal a kérdés szakértőjévé váló WALLISnak jutott (Naval Intelligence Department 1919). WALLIS ekkor már nem csak az RGS-ben és brit fórumokon mutatta be a magyarországi etnikai kérdéssel kapcsolatos álláspontját, hanem az Amerikai Földrajzi Társaság (AGS) folyóiratában is írt erről tanulmányt (WALLIS, B. 1917), később pedig egyes részletkérdéseket is elemzett a BowMAN irányításával múködő lapban.

Az amerikai Inquiry geográfusának, Douglas W. JoHnsonnak BowmANhez írt leveléből (2020) kiderül, hogy az információcsere a brit és az amerikai geográfusok között már a béketárgyalások elótt élénk volt. Az 1918. május 9-én keltezett (és a 2020-as emlékévben magyar nyelven is megjelent) forrásban JoHNSON beszámolt az 1918 április-májusi londoni útjáról, amelynek során felkereste a földrajzi hírszerzéssel foglalkozó brit szervezeteket. Ennek keretében találkozott HeDLEY-vel és OGILVIE-vel (a brit vezérkar földrajzi csoport- 
jában (GSGS)), Dicksonnal és WALLisszal (Naval Intelligence Department), illetve az RGS vezetőivel HoLDICH-csal és Hinksszel. Magyar szempontból a WALLISszal folytatott megbeszélése a legfontosabb, amelynek során megvitatták WALLIS etnikai térképeit, és JOHNSON engedélyt kapott arra is, hogy ezekről másolatot készítsen. HinKs cserébe azt kérte, hogy az Inquiry is biztosítson hozzáférést a brit kollégáknak a hasonló bizalmas amerikai anyagokhoz (JoHnson, D. 2020, pp. 203-204). GlanT TiBOR (2020, p. 31) véleménye szerint ez a brit-amerikai információcsere magyarázza, hogy az Inquiry osztrák-magyar csoportja 1918 nyarától már nem folytatta a korábban megkezdett statisztikai adatelemzést. Az amerikaiak valószínúleg magas színvonalúnak találták a Londonban beszerezett anyagokat, és elfogadták a brit álláspontot, azaz a magyarországi nemzetiségi ügyekben elsősorban WALLIS véleményét.

Ebből a rövid áttekintésből látható, hogy a brit földrajz Magyarország-képe a béketárgyalások megkezdése előtt nem volt ugyan teljesen egységes, de összességében inkább negatív volt. Jól dokumentált, hogyan veszítette el a brit közvéleményben Magyarország korábbi kedvező megítélését már a háború kitörése előtt (JESZENSZKY G. 1986), és úgy tűnik, hogy a földrajzosok is osztották ezt az elítélő véleményt. Hiába bíztak a magyar geográfusok a földrajzi érveik erejében, a személyes kapcsolataik segítségében, a magyar területi integritás megőrzésének nem maradt támogatója a kérdésben megszólaló brit geográfusok között 1918 őszére. Eltértek a vélemények abban is, hol húzódjanak az új magyar határok, és nem volt egyetértés abban sem, hogy a nemzetiségi választóvonalakat vagy a természetes határokat kövesse majd az új országhatár, de ahogy a brit (és az amerikai) külpolitika lemondott az Osztrák-Magyar Monarchia belső megreformálásáról és további fönntartásáról 1918 derekán (JESZENSZKY G. 2019), úgy a békeelőkészítésen dolgozó tudósok sem számoltak már a régi országhatárok megmaradásával.

\section{Határmegvonás háborúban és békében:} Alan OGILvie párizsi és londoni munkája

Alan Ogilvie és Walter CoOte Hedley már azelőtt ismerték egymást, mielőtt a párizsi és londoni közös munkát elkezdték volna. Először akkor találkoztak, amikor OGILVIE 1914 júliusában az RGS-ben a természeti földrajz és a térképészet kapcsolatáról tartott előadást (OGILVIE, A. 1915a). HedLEY ekkor a brit vezérkar földrajzi csoportjának (GSGS) a vezetője volt, OGILVIE pedig a földrajz egyik előadója Oxfordban, és éppen a Moray Firth partvidékének természeti földrajzát feldolgozó kutatását fejezte be (WITHERS, C. 2010b). OGILVIE 1915-ös tanulmánya fontosabb, mint a témája alapján elsőre gondolnánk. A természetföldrajzban és általában a földrajzi kutatásokban a térképek fontosságát hangsúlyozva, OGILVIE arra hívta föl a figyelmet, hogy a geomorfológiai kutatómunkának komoly akadálya, hogy a különböző méretarányú térképeket nehéz beszerezni, ezek általában drágák, és a különböző brit térképkibocsátó intézmények között alig van koordináció. OGILVIE geomorfológiai kérdésekről írt szakmai anyaga tükrözi a WILLIAM MoRIS DAVIS morfológiai módszerei iránti komoly érdeklődését (ami akár az 1912-es transzkontinentális utazás hatása is lehet), de nekünk most fontosabb a brit katonai térképezési hivatal, az Ordnance Survey felé megfogalmazott kritikája. Az előadást követő vitában mind HoLDICH, mind HINKS egyetértettek abban, hogy Ordnance Survey-nek, a GSGS-nek, és a földrajzi társaságoknak (mindenekelőtt az RGS-nek) többet kellene tenni azért, hogy különböző céloknak megfelelő térképeket állítsanak elő.

HEDLEY 1915 júliusában vette fel a kapcsolatot OGILVIE-vel a GSGS-nél végzendő munka ügyében. OGILVIE naplójába ezt a megjegyzést írta: „Ma a megbeszélt idópontban találkoztam W. C. HedLEy ezredessel, aki felkért, hogy térképészként dolgozzak a Közel-Keleten. 
Igent mondtam" (OGILvie, A. é.n., 1915. július 9.). Ekkor OGILvie már Franciaországban volt, és a 7. londoni tüzérezrednél teljesített szolgálatot. A közvetlen felettesének, a hírszerző főcsoport őrnagyának, DunNINGTON JEFFERSONnak írt levelében OGILVIE részletesebben (és saját képességeit szerényen kisebbítve) számolt be a rá váró térképészeti munkáról: „HEDLEY határozottan közölte, hogy a Közel-Keletre küld térképezési feladatokra, mivel engem gondol a legalkalmasabbnak erre munkára" (OGILVIE, A. 1915b). Valójában 1915. május 30-án OGILVIE maga jelentkezett hírszerzési feladatokra. Abban bízott, hogy földrajzi szaktudása, francia és német nyelvismerete (Párizsban és Berlinben is tanult a háború kitörése előtt) kvalifikálják erre, nem is említve a fontosnak vélt speciális képességét: „Tudok motorbiciklit vezetni, bár szerelni sohasem szereltem” (OGILVIE, A. 1915b). Ezek a források megerósítik, hogy az idő tájt az RGS és GSGS a Közel-Keletre fókuszált (HeFFERnAN, M. 1996), és rávilágítanak arra is, miért OGILVIE került az GSGS látókörébe.

OGILVIE azonban sohasem jutott el a Közel-Keletre. A parancsot megváltoztatták, és Szalonikibe rendelték, a Szaloniki Expedíciós Haderő vezérkarának térképező csoportjához. Ez a munkája a korábbi feldolgozásokban felderítetlen maradt (WITHERS, C. 2010b), pedig közvetlen kapcsolata van a párizsi szerepvállalásával és az 1922-es könyvével. A szaloniki térképészeti csoport négy szekcióra oszlott: terepi felmérés, a felmérések eredményeiből a térképek megrajzolása, ,térképek sokszorosítása a harcoló csapatok számára” és a térképek helyesbítése. OGILVIE volt a parancsnoka térképeket sokszorosító szekciónak, amit a főhadiszállás mellett, egy üresen álló kávéházban rendeztek be. A munka a térképek színezésétől, a harcálláspontok, frontszakaszok feltüntetésétől a kinyomtatott térképek ellenőrzéséig terjedt. A használt színek számától függően naponta 500-2300 térképlap készült el. A brit nyomdatechnika nem volt a legmodernebb: „a 45 éves gép állandó javítást igényelt, és mindig gond volt a regiszterrel", de még így is jobb volt, mint ami a szövetségeseik rendelkezésére állt. OGILVIE csoportja egyaránt kisegítette a térképező munkában a franciákat és szerb hadsereg topográfiai csoportját (OGILVIE, A. 1916). 1917 januárjában a négy szekciót egyesítették, és ez lehetőséget adott OGILVIE-nek arra, hogy a térképkészítés többi területén is tapasztalatot szerezzen, majd 1917 februárjában arra utasították, hogy utazzon Rómába: olasz szakértők segítségével a légifotózásnak a térképezésben való felhasználásról kellett tájékozódnia. Amikor 1918 márciusában HEDLEY a GSGS-be való áthelyezését rendelte el, nem volt kérdéses, hogy a brit geográfusok közül OGILVIE rendelkezett a legnagyobb gyakorlati tudással a térképkészítés, a térképek sokszorítása és a határmegvonás terén, és ő ismerte legjobban a térképek meggyőző erejét.

Néhány nappal az 1918. november 11-i fegyverszünet után OGILVIE tudására már újra szükség volt. HinKsnek, a társaság fótitkárának küldött levelében azt írta, hogy a Macedóniáról tervezett tanulmányának a beküldését előreláthatólag el kell halasztania, mert „ugyan még nem biztos, de valószínüleg külföldre kell utaznom a párizsi béketárgyalások idejére" (OGILvie, A. é.n., 1918. november 13.). 1919. február 6-án OGILVIE és HedLEY részt vettek az első ülésen a „Nagyhatalmak és Belgium Küldöttségei Geográfus Képviselöinek Konferenciáján”, ahol „a határozatokat még nem véglegesített formában térképre vitték, hogy a békekonferencián bemutathatók legyenek; ehhez bizalmasan az 1:1 milliós térképet és más térképeket bocsájtották a földrajzos szakértők rendelkezésére" (OGILVIE, A. é.n., 1919. február 6.). Erre a szervezetre utalt OGILVIE „Central Geographical Committeeként" (Központi Területi Bizottságként) a Boundary Settlementben (OGILVIE, A. 1922, p. 6). Ugyanaznap ezt írta HiNKS-nek: „Itt nagyüzemben zajlik a munka, ami azt eredményezheti, hogyha az Ég is úgy akarja, akkor a békekonferencia rövid és egyszerü lesz." (OGILVIE, A. é.n., 1919. február 6.). A munka azonban olyan hatalmasnak és bonyolultnak bizonyult (ahogy ezt 1922-ből visszatekintve meg is írta), hogy HEDLEY és HiNKS engedélyének elnyerése után bevonta a feleségét is a feladatokba: EvELYNnek az RGS könyvtárában kellett 
anyagokat összeállítania, amiket azután továbbított a férjének Párizsba. Emellett rendszeresen konzultált HinKsszel, előadásokat hallgatott, HoLDICH-csal és KELTIE-vel vett részt megbeszéléseken (Keltie-t még Oxfordból ismerte) (OGILvie, A. é.n., 1919. február 26. 1919. március 27., 1919. május 8., 1919. május 29.) Később pedig Párizsba utazott, hogy a férje munkáját a helyszínen segítse.

OGILVIE naplója 1919. februárjától kezdve a munkájára vonatkozó szúkszavú megjegyzésekkel van tele: „H. Nicolsont láttam el információkkal a görög-albán határ ügyében" (HAROLD NiCOLSON a brit delegáció tagja volt) (OGILvie, A. é.n., 1919. február 13.); „Lengyelország új térképnek tervén dolgoztunk” (OGILviE, A. é.n., 1919. február 14.); „Albánia, Szerbia és Bulgária határainak megvonása” (OGILvie, A. é.n., 1919. február 19.); „A Trákiában húzódó stratégiai fontosságú görög-bolgár határt amennyire csak lehet a nemzetiségi határon próbáltuk megrajzolni. A tervezetet HAROLD NICOLSONnak nyújtottuk be” (OGILVIE, A. é.n., 1919. február 21.). A munkatempó később sem csökkent: „Március 4-én, kedden egész nap a határokkal foglalkoztunk." Magyarországot először 1919. március 6-án említi meg a naplóban. Az aznapi megbeszélésen JOHNSON és DE MARTONNE, valamint egy olasz diplomata és OGILVIE vett részt, a téma pedig ,a csehszlovák-román-magyar határ volt". A következő este OGILviE CVIJIĆet, a délszláv delegáció földrajzos szakértőjét hívta megbeszélésre. 1919. március 16-án, vasárnap ünnepi ebéden találkoztak az 1912-es amerikai transzkontinentális utazás résztvevői, többek között DE MARTONNE, GALLOIS, Demangeon, Brunhes, Bowman, Johnson és Ogilvie. Ezután április elejéig Ogilvie „a jugoszláv határ ügyein” dolgozott (OGILviE, A. é.n., 1919. április 3.). „Lengyelország déli határa és a meanderezóf folyók" írta a naplójába április 7-én, majd pedig május 15-én: „egész nap Magyarország és a galíciai fegyverletétel kérdésén dolgoztunk”.

Ezek a bejegyzések jól illusztrálják a munka természetét és intenzitását, azt a feszített menetrendet, amire OGILVIE a Boundary Settlementben is utalt. További érdekességek is kiolvashatók azonban a naplóból. Akármilyen elfoglalt is volt OGILvIE Párizsban, azért talált időt arra, hogy a saját kutatásait is folytassa. Még 1912-ben vágott bele a glaciális morfológiával foglalkozó vizsgálataiba, és Párizsban PIERRE RABOT-val is tudott ebben a kérdésben konzultálni. A Macedóniával kapcsolatos kutatása pedig kétségkívül a szaloniki „terepmunkájának” és a párizsi határmegállapító és térképező munkájának gyümölcse. OGILVIE a macedón kutatását 1919. március 24-én mutatta be az RGS-ben (tehát amikor Párizsban is a munka sûrújében volt), és a tanulmány már a következó évben meg is jelent (OGILvIE, A. 1920). BowmAN felkérésére egy hasonló témájú cikket az AGS folyóiratában is publikált (OGILvie, A. 1921). OGILviE elnézést kért HinKs-tôl a kutatási anyaggal való késlekedése miatt: „bár nem akarok bünbakokat keresni, de jelenleg igazából a békemú kovácsainak a kezében vagyok" (OGILVIE, A. é.n., 1919. május 22.). Ekkor OGILVIE már fő́ként Harold TemPERlEY-vel, illetve Hedley-vel és Nicolsonnal dolgozott együtt. Naplójának 1919. május 24-én kelt bejegyzése szerint, TEMPERLEY egész délután azon vitázott az olasz delegációval, hogy pontosan melyik hegycsúcsokon jelöljék ki majd az új határt. Arra utasította OGILVIE-t, ,,tegyen meg mindent, hogy távol tartsa az olaszokat a hegytetóktöl, és ne adjon a kezükbe támadásra alkalmas, katonailag elönyös pozíciókat" (TEMPERLEY, H. 1920, p. 427). Úgy tûnik, hogy a természeti földrajzi adottságoknak és a katonai védhetóségnek a szerepe (amit HoLDICH mindig is hangsúlyozott) a határmegállapító munkában továbbra is fontos volt (legalábbis az olaszok esetében). TEMPERLEY hatkötetes History of the Peace Conference c. könyvében is bőségesen megtaláljuk OGILVIE keze munkáját. OGILVE négy térképet készített az I. kötethez, hetet a II.-hoz, és ahogy TEMPERLEY fogalmazott, OGILVIE volt felelős , az I., a II. és a III. kötet földrajzi tartalmáért” (TEMPERLEY, H. 1920, II, p. v). A TEMPERLEY irányítása alatt végzett munka magyarázza meg, miért kérte föl OGILVIE-t, hogy publikáljon a háború alatt és után végzett munkájáról. Ebből az 
ösztönzésben született meg a Boundary Settlement, ahogy erre OGILVIE is utal könyve előszavában (OGILVIE, A. 1922, p. iii).

Bármennyire is intenzív volt a béketárgyalások munkája, jutott idô a társasági életre is, amit a háború borzalmai után a kortársak közül többen is elítéltek (MACMILLAN, M. 2001, pp. 157-161). Temperley így írt erről: „Amikor szolgálaton kívül voltunk vagy együtt étkeztünk, nem volt tilos az éppen szóban forgó ügyek megvitatása. Söt, ezek az alkalmak minden szakértőnek páratlan lehetôséget biztosítottak, hogy az általa vizsgált részletkérdés kapcsolódási pontjait a többiekkel megbeszélje, és így az adott kérdést a békekonferencia egész problémahalmazában jobban elhelyezze" (TEMPERLEY, H. 1920, I, p. vi). Előfordult, hogy OGILVIE Arábiai LAWRENCE-szel vacsorázott: „,megbeszélés T. E. LAWRENCE-szel Szíriáról és a szíriai igényekról" (OGILVIE. A. é.n., 1919. február 18.), majd márciusban már Londonban az RGS-ben találkoztak újra. Ha OGILVIE nem TEMPERLEY-vel és NiCOLSONnal vacsorázott együtt, akkor legtöbbször a többi delegáció földrajzos szakértôivel ült asztalhoz: DE MARGERIE-vel, BowMANnal, JOHNSONnal. „Végig pletykákkal szórakoztatott minket", emlékezett vissza TEMPERLEY-vel eltöltött vacsorára EVELYN OGILVIE (OGILVIE, E.é.n., 1919. június 16.). A 2019. május 29-i munkáról ezt írta AlAn OGILVIE a naplójába: „Egy hosszú nap a békeszerződés ügyeiról. Délután a Quai d'Orsay-ban. Ausztria déli határának végsó megállapítása és a Klagenfurti-medencében népszavazás elrendelése. A „négyek” (WoOdrow Wilson, Lloyd George, GeOrges Clemenceau, VitTorio ORLANDO, olasz miniszterelnök) reggel döntöttek. A Központi Területi Bizottság ülésén nyilvánvalóvá vált, hogy mivel a miniszterek távol maradtak a „négyek” ülésétól, ezért véleménykülönbség alakult ki döntésröl. CVIJIĆ-csel és a feleségével vacsoráztam, GALLOIS, DE MARGERIE és JOHNSON is ott volt. Vacsora után arról beszélgettünk, jó lenne majd alapítani egy nemzetközi földrajzi folyóiratot vagy évkönyvet, amiben a nagyobb munkák is megjelenhetnek. Olyasmit, mint a Petermanns Mitteilungen" (OGILvie, A. é.n., 1919. május 29.).

A különböző nemzetek geográfusai a párizsi békekonferencián lehetőséget kaptak, hogy Európa határainak főleg etnikai, de helyenként természeti földrajzi vonalakhoz illeszkedő átrajzolásánál a szakértelmüket bizonyítsák - DE MARTONNE Románia, ROMER Lengyelország, CviJić Jugoszlávia, OGILvIE és mások pedig általában az európai határok esetében (PAlsky, G. 2002; Ginsburger, N. 2016; LABbé, M. 2018). Munkájukban a különböző alapelvek között kellett kompromisszumot teremteni, az etnikai elv kiemelt érvényesítésével. OGILvie Boundary Settlement c. könyve ezt a munkát mutatja be. Még BOWMAN is bevallotta azonban, hogy a térképező munka helyenként gyenge minőségû volt. OGILVE-nek 1919 szeptemberében küldött levelében (OGILVIE manchesteri kinevezéséhez gratulált), BowMAN megemlítette, hogy átküld „,néhány alaptérképet és folyamatábrát, amiket itt az American Geographical Society-ben a békekonferenciához készítettek. Ha használod óket, vedd majd figyelembe, hogy nagy sietséggel készültek, többségüket a szakmában járatlan rajzolók csinálták, így sok hiba lehet rajtuk" (BowMAN, I. 1919). A párizsi konferencia lehetőséget teremtett alapvető földrajzi kérdések nemzetközi megvitatására abban az időszakban, amikor a diszciplína intézményi háttere Amerikában és Nagy-Britanniában éppen kiformálódóban volt (Dunbar, G. 2001; MARTIN, G. 2015). Amikor OGILviE együtt dolgozott BowmAnnal, JoHnSONnal és DE MARGERIE-vel a jövő európai politikai földrajzának megrajzolásán, egyúttal azt is látnia kellett, hogy a korabeli brit földrajz hiányosságokkal küzd.

\section{Intézményi különbségek, személyes lehetôségek}

1919. április 2-án, egy „csendes napon”, a Bois de Boulogne-ban tett hosszú séta után OGILVIE egy „privát” megjelölésú levelet írt HinKsnek. A levél egy részében OGILVIE sze- 
mélyes dilemmáját osztotta meg HinKS-szel: HenRY DicKsontól (aki a háború alatt az Admiralitás tengerészeti hírszerzésének földrajzi csoportját vezette, civilben pedig geográfus és meteorológus volt) megtudta, hogy Oxfordban egy földrajzos docensi állást fognak kiírni, amire szívesen pályázott is volna. OGILVIE amiatt aggódott, hogy ha a pályázata sikeres lesz, akkor lehet, hogy a barátját, az Oxforban tanító H. O. BECKITet üti el az előléptetéstôl. (Végül BECKIT kapta meg a kinevezést). De ez csak egy bevezetés volt levele valódi üzenetéhez:

„Bizonyára emlékszik arra a beszélgetésünkre, amit a földrajz közvetlen állami kormányzati szerepvállalásáról folytatottunk. Napról napra erösödik az a meggyózódésem, hogy egy ilyen szervezet az összes minisztériumnak hasznára lenne. Remélem, hogy Lord CURZON és AMERY benyújtja a kormánynak ezt a tervezetet, és valószínúnek tartom, hogy az RGS-tól is fognak hivatalos véleményt kérni. Teljesen nyilvánvaló, hogy a Társasággal való valamilyen együttmüködés elengedhetetlen lesz a szervezet múködtetéséhez, és az is biztos, hogy a tervezet elfogadása esetén egy vagy több geográfusra is szükség lesz. A geográfusoknak (vagy legalábbis egyiküknek) ráadásul jó kapcsolatteremtó képességgel kell rendelkeznie, hogy a mindennapi munka során a különbözó minisztériumokkal érintkezésbe tudjon lépni: a jó diplomáciai érzék elengedhetetlen. Sokat gondolkodtam mostanában ezen a dolgon, és ószintén mondom, anélkül, hogy eleve erre a következtetésre akartam volna kilyukadni, arra jutottam, hogy nincs nálam alkalmasabb erre a pozícióra. [...] Az tény, hogy a Londonban és itt Párizsban végzett munkám elég jó bepillantást engedett abban, hogy a különböző minisztériumoknak mire van szüksége, és jól látom a jelenlegi tendenciákat is (OGILVIE, A. 1919).

Nem tudjuk pontosan, mikor zajlott le OGILVIE és HinKs között a levélben említett korábbi beszélgetés. HinKs és HEDLEY 1919. január elején már leveleztek erről. HinKs egy „új Geographical Department" javaslatának lehetőségét körvonalazta, a Memorandum benyújtását pedig „személyes felelóségének” nevezte. A karácsonykor elkészített Memorandum kapcsán viszont HinKs még óvatos volt: „,nincs még itt az idő, hogy erról az RGS elnökével és választmányával tanácskozzunk" (Hinks, A. 1919). A memorandum egy dátum nélküli gépiratként maradt meg („A kormányzati felhasználásra szánt földrajzi információk gyüjtésének és feldolgozásánakfontosságáról"), és rávilágít arra, milyen hiányosságokkal küzdött a korabeli brit földrajz a háború, majd a béke idején.

A brit vezérkar földrajzi csoportja (GSGS) kitűnően oldotta meg feladatát a háború alatt, de a katonai térképezésért felelős Ordnance Survey (OS) „,nem tudott hasonló színvonalú általános földrajzi munkát végezni”. A brit katonai hírszerzés földrajzi részlegei erősen támaszkodtak az RGS-re. „A sok újonnan felállított csoport között nagy volt az átfedés és emiatt az eróforrás-pazarlás a kormány által igényelt földrajzi kézikönyvek, illetve szakmai anyagok elkészítésénél, a háború alatt és a béke-elókészitó munkában egyaránt”. Az RGS ugyanakkor a brit földrajzi koordináció jól múködő központja volt: „A Társaság alá rendelt Földrajzi Kormányiroda felállitása a természetes továbbfejlesztése lenne azoknak a szolgálatoknak, amelyeket a Társaság mindig is teljesített, és különösen a háború négy évében az egész nemzet érdekében megtett" (HINKS, A. 1918). A javaslat szerint az egyetemeket és a tudományos társaságokat szintén be kellene vonni ennek a szervezetnek a múködésébe. Valójában ezek OGILVIE ötletei és tervei voltak, és a saját tapasztalatiból fakadtak. A felsőbb hatóságok elé terjesztésük HiNKs dolga lett volna, de a nehezen megnyert háború következményeként és a rossz időzítés miatt (1918 karácsonya) ez végül nem történt meg.

Mindez szorosan kötődik a párizsi béke-előkészítő, térképező és határmegállapító munkához is. OGILVIE egyrészt a béketárgyalások vezető brit geográfusaként, másrészt korábbi tapasztalataiból fakadóan mindenki másnál pontosabban tudta, hogy milyen fajta földrajzi munkát lehetne a kormány számára (vagy a kormány egyik irodájaként) elvégezni. Az 
RGS koordinálta az 1:1 milliós térkép projektjét Nagy-Britanniában. A Magyarországról Párizsban és Londonban készített térképek ebből a projektből kiindulva, annak továbbfejlesztéséhez kapcsolódva jöttek létre. Londonban WALLIS, LYDE és HoLDICH már 1915-től (éppen Magyarország példáján) értekeztek az eltérő módszertannal készített térképekrôl és az eltérő elvek alapján meghúzható politikai határokról. 1919-től kezdve pedig Párizsban ugyanez a munka folytatódott: Magyarország térképezése, határainak átrajzolása már az új európai területi rendezés része volt.

OGILVIE HinKsnek küldött levele egyszerre mutatja meg személyes ambícióit és a különböző kormányzati intézmények földrajzi munkájával való elégedetlenségét. HinKSnek HEDLEY-hez írt levele és OGILVIE sürgetésére elkészített memoranduma viszont arra is rámutat, amikor Európa határait átrajzolták (a legutoljára és legdrasztikusabban Magyarország határait), akkor a brit földrajzosok körében nem volt általánosan elfogadott vélemény az egész folyamatról, az új határok jellegéról az intézményi koordinációról és a szükséges térképezésről.

OGILVIE 1915-ös tanulmányának megjegyzései a térképezésről és a brit földrajzi intézmények közötti koordinációról már előre jelezték a gondokat: a brit geográfusok közti véleménykülönbségek kitapinthatók voltak. Nagy-Britannia vezető geopolitikusa, HALFORD MACKINDER a földrajzot mindig is államvezetés szolgálatában képzelte el (MACKINDER, H. 1919; PARKER, W. H. 1982). Ot mégsem vonták be az 1918 utáni határmegvonás tényleges munkájába (KEARNS, G. 2009), ez megmaradt az RGS-ben HinKS, LydE és HoLdicH felségterületének, Párizsban brit részről OGILVIE-nek és HEDLEY-nek, amerikai részről pedig BowmANnek és az AGS-nek. HinKS az RGS-ben ellentmondást nem tûrő vezetési stílusával és a Társaság folyóiratának, a Geographical Journalnek erőskezú főszerkesztői irányításával nem sok barátot szerzett magának. HEFFERNAN ír arról, hogy HiNKS-et megdöbbentette BowMAN folyamatos kérése az RGS 1:1 milliós térképének és a GSGS háborús térképeinek az átadásáról, a viszonyuk gyorsan megromlott, és ,kölcsönös, élethosszig tartó megvetéssé fajult" (HEFFERnAN, M. 1996, p. 521). A csillagász képzettségú HINKs, aki a legtöbbre a precizitást és a szabatosságot becsülte, soha nem kedvelte meg igazán a korban egyre fontosabbá váló, „,modern” társadalomföldrajz ágazatait (WITHERS, C.-Finnegan, D.-HiggitT, R. 2006). Bowman még 1930-ban is gúnyolódó szavakkal írt OGILVIE-nek Hinksről: „Jut eszembe, biztos érdekel az friss hír, hogy néhány itteni geográfus keményen nekiment az RGS-nek a Geographical Journal jellege miatt. Ránézésre teljes gyözelmet arattunk. De biztos, hogy az öreg Hinks hajthatatlan marad-majd az idö megmutatja, hogy sikerül-e a Journalban valami újba kezdeni" (BowMAN, I. 1930). HiNKS erős kontrollja a Geographical Journal fölött, BowMAN és az amerikai delegáció iránti ellenszenve, továbbá az elkötelezettsége, hogy az RGS-t továbbra is megórzi a legtekintélyesebb földrajzi intézménynek (annak ellenére, hogy a határmegvonásoknál az RGS vezető személyiségei nem tudtak közös véleményre jutni) ahhoz vezettek, hogy azok a brit geográfusok, akiket az új Európa érdekelt, más fórumot kerestek, hogy megkisebbedett Magyarország helyzetét megvitassák.

\section{A brit földrajzosok és a magyar kérdés a British Association for the Advancement of Science konferenciáin (1915-1922)}

A British Association for the Advancement of Science (BAAS) E (Földrajz) Szekciójának éves konferenciái a földrajz fejlesztésének és népszerúsítésének élénk fórumai voltak, különösen a 20. század elején. Az RGS szoros kapcsolatban állt a kormányzati körökkel, népszerűsítő előadásokat szervezett, támogatta a földrajzi tanszékek felállítását számos brit egyete- 
men, de mégis valamiféle „tudományos válsággal” küzdött a 20. század elején (WITHERS, C. 2010a, pp. 198-231). A társaság túl későn szervezte meg a kutatási bizottságát, elhanyagolta a társadalomföldrajzot, hogy továbbra is a felfedezésekről szóló előadásokat és cikkeket részesíthesse előnyben (legalábbis a társadalomföldrajzosok első generációja szerint). Ez részben visszavezethető arra, hogy HinKs, aki személyes ellenszenvet táplált a társadalomföldrajz iránt, nem engedte ki a kezéből a Geographical Journal irányítását - 1. BowMAN megjegyzését az OGILVIE-nek 1930-ban írt leveléből. Az 1930-as évek elejéig még mindig kitapintható volt az, amit az RGS elnöke így fogalmazott meg: ,, a Társaság hajlamos volt megfeledkezni a földrajz társadalmi és oktatási oldaláról" (WITHERS, C. 2010a, p. 223). Emiatt a korabeli földrajzosok nagyra értékelték, hogy a NEWBIGIN szerkesztésében megjelenő Scottish Geographical Magazine sokkal nagyobb hangsúlyt fektetett a kutatási eredmények publikálására,és a BAAS konferenciák pedig megfelelő fórumot biztosítottak a szakmai vitákra.

HiNKS és WALLIS egyaránt tartott előadást a BAAS 1915-ös manchesteri konferenciáján. HiNKS a társaság által gondozott 1:1 milliós térkép munkálatairól beszélt, WALLIS pedig az etnikai térképezés nehézségeit mutatta be, illetve az eltérő módszerrel készült térképeket hasonlította össze az 1:1 milliós térkép budapesti szelvényén (MCFARLANE, J. 1915, p. 375). Az E (Földrajz) Szekció elnöke, H. G. LYONS írásban megjelent beszédében (a háború miatt nem tudta személyesen megtartani az előadást) azt hangsúlyozta, hogy földrajzi kutatásokra van szükség, illetve „a tudományos földrajz fejlesztésére” (LYONS, H. G. 1915, p. 269). A háború nemcsak LYONs konferencia-részvételét akadályozta, hanem BAAS múködését is. A résztvevők száma alacsony volt Manchesterben, HiNKS szerint ,,meglehetösen furcsa, szinte élettelen konferencia volt”, ugyanakkor „mégis örültem annak, hogy elmentem, mert így személyesen is megismerhettem Miss Newbigint" (HinKs, A. 1915). A részvétel Newcastle-ben is csekély volt 1916-ban, 1917-ben és 1918-ban pedig nem is tartottak konferenciát (WiTHERS, C. 2010a, p. 49). Magyarország és az átalakult Európa iránti érdeklődés csak az I. világháború után újult meg.

MARION NEWBIGIN néhány héttel a háború vége után már publikálta az 1918. novemberi fegyverletétel földrajzi fontosságáról szóló tanulmányát, aminek megállapításai természetesen az ideiglenességnek a jegyeit is magukon viselték (n. n. 1918). Általában óvatosan fogalmazott: „a fegyverletétel feltételeit ábrázoló részletes térkép közlése most még nem lehetséges" (n. n. 1918, p. 441). Úgy tünhet viszont, hogy NEWBIGIN olyan bizalmas információkhoz is hozzájutott, amelyek akkoriban még nem voltak köztudomásúak, így például írt ,az osztrák-magyar területek kiürítési vonalának pontos futásáról” szóló javaslatokról (n. n. 1918, p. 443). Ha figyelembe vesszük OGILVIE fentebb közölt információit a saját és többiek párizsi munkájának dátumairól (1919. február-május), valószínútlen, hogy NeWBIGIN biztosat tudott volna. Sokkal inkább tükrözte ez NEWBIGIN alapos kelet-közép-európai tájékozottságát (NEWBiGin, M. 1915a, 1915b), hallotta HinKs és WALLIS manchesteri előadásait, és maga is ismerte az etnikumok és nemzetiségek térképezésnek nehézségeit (NEWBIGIN, M. 1917). (NEWBIGIN 1915-ös könyvéről készített recenziójában Teleki is elismerően írt a skót geográfus közép- és délkelet-európai ismereteiről és jó meglátásairól [TELEKI P. 1922].) Nincs arra utaló bizonyíték, hogy NEwBigin találkozott volna OGILVIE-vel, és megvitatták volna az európai határok megvonásának és térképezésének ügyét. Találkoztak viszont az 1922-es BAAS konferencián Hullban, ahol NEWBIGIN már az E Szekció elnöke volt, és az ,új társadalomföldrajzról” tartott előadást (NEWBIGIN, M. 1922b; 1923). LYDE, MCFARlane és RUDMOSE BROWN szintén azok között voltak Hullban, akikkel OGILVE „találkozott és beszélgetett" (OGILvie, A. é.n., 1922. szeptember 22.).

NEwBigin az új Európa politikai földrajzával foglalkozott az első háború utáni BAAS konferencián, 1919-ben, Bournemouth-ban, amikor a nacionalizmus és az „új nemzetköziség” kérdéseiről beszélt (Newbigin, M. 1921). Szintén politikai földrajzi problémát 
választott az E Szekció elnöke LIONEL LYDE is, aki a folyókról mint lehetséges nemzeti és „nemzetközi” határokról tartott előadást (egy régi témáját felelevenítve ezzel). „Elöadásom tárgyát még a békeszerződés nyilvánossá tétele elöt választottam ki, mert szerettem volna a földrajzi hitvallásomat az „amerikanizált” Európa politikai földrajzával összevetni” (LyDE, L. 1921, p. 212). Hallgatóságát arra emlékeztette, hogy „,az elmúlt években mindig amellett foglaltam állást, hogy a folyókat érdemes politikai határoknak választani" (LYDE, L. 1921, p. 213). LYDE kiemelte: nem akarja aláaknázni az etnikai alapelvet, ami Trianonhoz és az új Európa határainak megrajzoláshoz vezetett, de a háborúból kiláboló világ új nemzetközi rendje mellett száll síkra. „Meg kell órizni a politikai és kulturális egységekre épülö értékes sokszínüséget, de össze kell vonni ezeket egységeket. A cél az egység és nem az egyformaság" (LYDE, L. 1921, p. 213). LYDE beszéde értelmezhetô egy másfajta határmegrajzolási alapelv melletti sikertelen kiállásként is: bizonyos, hogy az európai béketárgyalásokon résztvevó geográfusok nem ezt az alapelvet választották (de az is biztos, hogy HoLDICH sem ezt szorgalmazta). Nem szabad azonban szem elől tévesztenünk, hogy LYDE éppen egy olyan időszakban tartotta meg a nemzetköziség mellett érvelő előadását (ahogy NEWBigin, Lyons és mások is), amikor maga társadalomföldrajz is küzdött azzal, hogy meghatározza saját kutatási területét, tartalmát, episztemikus határait. Egyformán igaz ez Lengyelországra, a későbbi Jugoszláviára, Romániára, de éppúgy Nagy-Britanniára, az Egyesült Államokra vagy éppen Magyarországra.

Hozzájuk hasonlóan az E Szekció elnökeként JoHN McFARLANE is a háború utáni európai berendezkedését választotta elnöki nyitóelőadása témájának BAAS cardiffi konferenciáján, 1920. augusztus 24-én (McFarlane, J. 1920). Newbigin és OGilvie 1922 előtti személyes kapcsolatára nincs bizonyítékunk (bár elképzelhető, hogy NEWBIGIN támaszkodott OGILVIE párizsi tapasztalataira az 1918-as tanulmánya és 1920-s könyve megírásakor), az viszont bizonyos, hogy McFARLANE hallotta OGILVIE-t a témáról beszélni. OGILVIE 1919 júniusában fejezte be Párizsban a munkáját, és a Manchesteri Egyetemre ment tanítani. Rövid idejü volt a manchesteri adjunktusi pályafutása, viszont 1919. november 5-én a Manchesteri Földrajzi Társaság szervezésében tartott egy előadást „,mintegy 40 fös közönségnek” „Földrajz a békekonferencián” címmel (OGILVIE, E. é.n., 1919. november 5.). Azt persze nem tudjuk megállapítani, hogy mennyit merített OGILVIE 1919-es előadásából vagy NEwBIGIN 1920-as könyvéből McFARLANE a saját előadásához és tanulmányához, de ha csupán végig tekintünk az éves konferenciákon elmondott elnöki nyitóbeszédek során, a megjelent tanulmányok, a konferencia-előadások listáján, jól látható, hogy a háború utáni európai berendezkedés és Magyarország iránti érdeklődés erős volt.

MCFARLANE érvelése világos volt: „Az európai államok határainak átrajzolása során a földrajzi tényezóket nem vették olyan mértékben figyelembe, mint kellett volna" (MCFARLANE, J. 1920, p. 217). MCFARLANE nem azokra a földrajzi tényezőkre gondolt, amelyek mellett HOLDICH tört lándzsát - „, a természetes védelmi vonalak” (MCFARLANE J. 1920, p. 218) -, hanem sokkal inkább a népek önrendelkezési jogát emelte ki, ami WILSON Új-Európa tervének is központi elemét képezte volna (MaCMILlan, M.. 2001; ToOzE, A. 2014; SEEGEL, S. 2018; BowmAn, I. 1921). MCFARLANE szerint az etnikai alapú határmegvonás utolsó pillanatában végül eltekintettek ettől az elvtől. Nem az volt a gond, hogy teljesen figyelmen kívül hagyták a wilsoni elvet, hanem az, hogy egyenlőtlenül alkalmazták. „Azt hiszem, hogy az igazi stabilitást azoknál az eseteknél remélhetjuik, ahol az etnikai és földrajzi tényezók a legnagyobb harmóniában vannak, és azok lesznek instabilak, ahol sem a földrajzi, sem az etnikai tényezók nem kaptak megfeleló súlyt" (MCFARLANE, J. 1920, p. 218). Lengyelország most ,földrajzilag gyenge”, Csehszlovákia „többféle szempontból is az új Európa legérdekesebb országa" (MCFARLANE, J. 1920, pp. 221, 224). Magyarországgal külön is foglalkozott MCFARLANE, a határmegvonásnak az Alföld „hatalmas természe- 
tes régiójára” és ,az azt övező hegyvidéki tájakra” gyakorolt hatása miatt (MCFARLANE, J. 1920, p. 227). „A legtöbb bírálat a békeszerződések területi határozatait a Magyarmedencével való bánásmód miatt érheti. A földrajzi alapelveket eröszakkal hágták át annak a régiónak a szétdarabolásával, ahol a magyarok többségben voltak, ráadásul arányuk a lakosságon belül növekvő volt”. MCFARLANE hangsúlyozta: „Ez az egész helyzet az instabilitáshoz vezet. ... Európának ezen a részén a Népszövetségnek nem kell majd sokáig várnia a bajok kezdetére" (MCFARLANE, J. 1920, pp. 227-228).

MCFARLANE elóadása nem maradt visszhang nélkül a magyar geográfusok körében sem. A Földrajzi Közlemények 1922-es évfolyamában FEST ALADÁR közölt alapos recenziót az előadás anyagából született részletes tanulmányról. A magyar recenzens az európai szakmai közhangulat megváltozását emelte ki MCFARLANE gondolatainak interpretálásakor: „Amint látjuk, a külföld elfogulatlan szaktudósaiban már eléggé kialakult a háború által teremtett földrajzpolitikai képtelenségek tudata. A mi földrajzi társaságunkra vár az a fontos feladat, hogy ezt a tudatot kellö felvilágosítással és adatközléssel az érdeklödó külföldi tudományos, körökben folyton ébren tartsa és erösitse, az esetleges tévedéseket helyesbítse és elleneink célzatos ferdítéseit ellensúlyozza" (FEST A. 1922, p. 180).

Az új Európáról és Magyarország szétdarabolásáról a háború utáni BAAS konferenciákon megfogalmazott vélemények (akár a fegyverszünet után [n. n. 1918], akár Trianont követően [LYDE, L. 1921; MCFARLANE, J. 1920] a korábbi, illetve máshol felvetett témákhoz kapcsolódnak: a határmegvonás különböző lehetőségei, a nemzetiségi elv alkalmazása Európa új határainál. Feltűnő módon nem volt egyetértés a határok pontos futását, illetve a hosszú távú következményeket illetően. McFARLANE így összegezte a lezajlott eseményeket: „Az új európai berendezkedés egy hatalmas kísérlet” (MCFARLANE, J. 1920, p. 232), de sem ő, sem mások nem voltak derúlátók a kísérlet jövőbeli sikerét illetően.

\section{Összefoglalás}

Kétrészes tanulmányunkban azt mutattuk be, milyen szerepet játszottak az I. világháború utáni európai határmegvonásoknál egyes geográfusok, illetve a földrajztudomány egésze. A levéltári források feltárása és a megjelent publikációk elemzése során képet kaptunk arról, hogy az 1910-es években a brit geográfusok Magyarországról alkotott véleménye (a nagy-britanniai közvéleményhez hasonlóan) közömbös vagy elítélő volt. Az utolsó háborús évben, amikor a brit külpolitika már elkötelezte magát a Monarchia felszámolása mellett, Magyarország területi integritásának nem maradt támogatója brit geográfusok között sem. Teleki Pál és munkatársai az összeomlás közepette dolgozták ki az ország egysége melletti komplex földrajzi érvrendszert, és készítették el a meggyőző erejű térképeket. Hiába bíztak azonban a nemzetközi kapcsolatrendszerük mozgósításában, a brit kollégáknak címzett személyes leveleik válasz nélkül maradtak, és a szakmai anyagok, térképek sem változtatták meg a békekonferencia területi döntéseit. Valószínúleg erre lehetőségük sem volt, hiszen a békeszerződések területi kérdéseiben az alapvető döntéseket nem a geográfusok hozták, azokat a nagyhatalmi érdekek szabták meg. A tudományos érvek sok esetben pusztán legitimációs eszközt, retorikai muníciót szolgáltattak a politikusoknak. A határmegvonás alapelveit illetően nem volt egyetértés a brit földrajzosok között a béketárgyalások előtt és a béketárgyalások után sem, de a Magyarországgal kapcsolatos álláspontjukban érzékelhető egyfajta változás: 1920 után többen is szót emeltek az új magyar határok problémái miatt.

A földrajzosok részvételének feltárása az 1920-as trianoni békeszerződés előkészítésénél, a sajátos földrajzi termékek (az etnikai térképek) vizsgálata, a tanácskozások, megbeszélések 
helyszínének felderítése (pl. a párizsi hotelek, az RGS Londonban, a BAAS konferenciák) a tágabb tudománytörténeti kutatás számára is nyújtott tanulságokat. Az egyik ilyen tanulság a kritikai és kontextualizált életrajzírás fontossága (BARNES, T. 2001). Tanulmányunk megírásánál kulcsfontosságú volt OGILVIE kéziratos hagyatékának feldolgozása, de az új Európa megalkotásában részt vevők közül mások is leírták saját történetüket publikált vagy kiadatlan visszaemlékezésükben (LANSING, R. 1921; BOWMAN, I. 1921; NiCOLSON, H. 1933; Temperley, H. 1920; CHOLNOKY J. 1998; FodOR F. 2016). A másik tanulság a kiemelkedő geográfusok és a nemzetközi kapcsolatrendszer szerepe a 20. század eleji földrajz egyetemes és nemzeti kontextusának kiformálásában (SMITH, N. 2003; SEEGEL, S. 2018). A harmadik pedig annak bemutatása, hogy a geográfusok lényegében az állami térképezési hivatalok feladatát látták el Európa háború utáni határainak megrajzoláskor (BowMAN, I. 1921; DHAND, O. 2018; SEEGEL, S. 2018). A brit földrajz története iránt érdeklődők számára ki lehet emelni, hogy a diszciplína kiformálódásának időszakában a BAAS biztosította a megfelelő kereteket a viták lefolytatására (WITHERS, C. 2010a).

Elemzésünk arra is rámutatott, hogy a térképeken csak egyszerú vonalként megjelenő határok és az ezeket kijelölő békeszerződések, más és más dolgokat jelentenek a különböző embereknek. A magyarok és a magyar geográfusok Magyarország trianoni feldarabolását (akkor és most is) az európai földrajzosok békeelőkészítő tevékenységének keserű következményeként élhetik meg. A brit földrajzosok, különösen ALAN OGILVIE, fontos szerepet töltöttek be ebben a béke-előkészítő folyamatban. Ahogy kutatásunkból kiderült, ezt a szerepet nem értelmezhetjük egyszerúen az elfogadott politikai és földrajzi alapelvek (ahogy 1922-ben OGILvIE fogalmazott, ,az alappontok”) végrehajtásaként, a személyes kapcsolatrendszer (Párizsban és Londonban egyaránt), a határok jellegéről vallott eltérő vélemények, maga a határmegvonás folyamata is befolyásolta a végeredményt.

ARTHuR Hinks és Alan OgILviE egyetértett abban, hogy a brit földrajzosok I. világháborús szakértői munkáját nem segítette, hogy a kormány a földrajzi és térképező munkát több eltérő kvalitású szervezet között osztotta meg. Magyarország etnikai földrajzi térképezésének (és a lehetséges új határok kijelölésének) nehézségeivel már 1915-ben szembesültek a brit geográfusok. De miközben Londonban WALLIS és HiNks az etnikai alapú határmegvonást gondolta a legjobbnak Magyarország esetében (ahogy 1919 februárjától OGILVIE és az GSGS csoportja is Párizsban), addig az RGS más tagjai, máshova helyezték a hangsúlyt: LYDE a folyókat, HOLDICH a domborzatot, a hegygerinceket tartotta ideális határnak. Londonban a geográfusoknak nem volt egységes véleménye a határmegvonás alapelveiról és Magyarország határairól.

Párizsban más volt a helyzet. Európa határainak feszített ütemú átrajzolása és a Központi Területi Bizottság számára a határmeg vonó munkáról készített rendszeres jelentések mögött látszólag egyetlen alapelv állt: a nemzetek önrendelkezésének joga és az etnikai alapú Új-Európa kialakítása. OGILVIE viszont 1922-es könyvében expliciten is kimondta, amit 1919 februárja és májusa között megtapasztalt: az alapelvekhez nem ragaszkodtak következetesen, főleg akkor nem, ha azok egymással is ütköztek (pl. a vasúti, közlekedési vonalak futása vagy a gazdasági érdekek és az etnikai megoszlás ütközése esetén). Magyarországon ráadásul a nyelvhasználatra épülő etnikai lehatárolást nem lehetett anélkül alkalmazni, hogy ne került volna nagyon sok magyar anyanyelvú ember a trianoni országhatárokon túlra. OGILviE határokkal kapcsolatos munkássága nem zárult le a GSGS-ból való kilépésével, ahogy ezt a 1919. novemberi manchesteri előadása is bizonyítja. EvELYN OGILVIE naplójába azt jegyezte be 1920 júniusában, miközben a New York-i költözésükhöz készülődtek, hogy a férje TEMPERLEY számára „a határokkal kapcsolatos munkán dolgozik” (OGILVIE, E. é.n., 1920. június 19.). 
Az I. világháború utáni brit béke-előkészítő munka vizsgálata kibővíti MICHAEL HEFFERNAN korábbi, az 1914-1918-as időszakot feltáró eredményeit, és OGILVIE saját tapasztalatainak bemutatásával segít azt is megmagyarázni, hogy a brit földrajz pozíciója miért volt relatíve gyenge, és miért volt a különböző brit intézmények térképező munkája annyira egyenetlen. Nem annyira a brit földrajz ,ez idő tájt döntően amatór jellegét” látjuk a háttérben meghúzódni (HEFFERNAN, M. 1996, p. 521), a kutatásunk sokkal összetettebb okokat derített fel: erősen eltértek a nézetek a kialakítandó határok jellegéről, nem volt egyetértés a megfelelő térképezési módszerekről, sőt a térképekben is hiány mutatkozott, és nem volt egységes álláspont a politikai alapelvekről sem. Amikor az RGS tagjai különbözőképpen foglaltak állást az ideális nemzeti határok ügyében, akkor a BAAS konferenciái teremtettek fórumot ezeknek a kérdéseknek a nyilvános megvitatására, és egyben lehetőséget is adtak arra, hogy McFARLANE, J. (1920) és LydE, L. (1921) aggodalmuknak adjanak hangot Európa 1918 utáni területi rendezése kapcsán. Trianon drámai volt, de nem volt egyedi. HoLDICH azt emelte ki, hogy akármilyen módon rendezik át Európa határait, a kontinens már soha nem lesz olyan, mint volt: „Talán nincs egy nemzet sem KözépEurópa és Perzsia között, amelyik pontosan ugyanazt helyet foglalja el, mint a háború elött” (Holdich, T. 1918, p. ix). Bowman hasonló véleményt fogalmazott meg: „A nagy háború következményei olyan messze hatók, hogy egyenesen egy új világról kell beszélnünk" (BowmAN, I. 1922, 1). Mindkettőjüknek igaza volt.

Jó pár évvel a párizsi munkája után, az Edinburgh-i Egyetemen megtartott székfoglaló előadásában OGILVIE így utalt vissza az új határokra és a határok kialakításában betöltött szerepére: „Világosan látszik, hogy Európa új határai nem tökéletesek” „Mindannyian tudjuk, hogy ezeket a határokat nem a béke nyugodt légkörében rögzítették, hanem akkor, amikor a politika levegóje a történelem legnagyobb viharzónájában még mindig örvénylett" (OGILvie, A. 1924, p. 74). OGILviE ezzel együtt is úgy látta, hogy szükséges volt „a földrajz intenzív bekapcsolódása a határmegvonás folyamatába”, mert a modern földrajztudomány éppen az ilyen „nagy kérdések” tanulmányozására hivatott, és a földrajz hasznos segítséget nyújt ezek jobb megértéhez (OGILVIE, A. 1924, p. 73).

\section{Köszönetnyilvánítás}

A kutatás lefolytatását a Magyar Tudományos Akadémia és a Royal Society of Edinburgh Kétoldalú Nemzetközi Együttmúködése tette lehetővé. GYŐRI RÓBERT kutatásait az NKFIH K 125001 projektje támogatta. A szerzők szeretnének köszönetet mondani az American Geographical Society munkatársainak, hogy elérhetővé tették a BowMAN-OGILvIE levelezést, továbbá EugENE RAE-nek, a Royal Geographical Society (with IBG) (London) levéltárosának és a Magyar Földrajzi Múzeum (Érd) munkatársainak a levéltári anyagok kutatásában nyújtott segítségükért. Külön szeretnénk megköszönni a néhai ELSPETH Collinsnak, Alan OGILVIE unokájának azért, hogy Alan OGILVIE és felesége naplóit rendelkezésünkre bocsájtotta, majd ezek a forrásokat a University of Edinburgh Library, Centre for Research Collectionsban helyezte el.

\section{GYŐRI RÓBERT}

ELTE TTK FFI Társadalom- és Gazdaságföldrajzi Tanszék, Budapest

„Trianon 100” MTA-Lendület Kutatócsoport, Budapest

gyorirobert@caesar.elte.hu 


\section{IRODALOM}

BARNES, T. 2001: Lives lived and lives told: biographies of geography's quantitative revolution. - Environment and Planning D: Society and Space 19. pp. 409-429.

BeLloc, H. 1915: The geography of the war. - The Geographical Journal, 45. pp. 1-13.

Bowman, I. 1919: Isaiah Bowman levele Alan G. Ogilvie-nek, 1919. szeptember 16. - American Geographical Society Library. University of Wisconsin-Milwaukee Libraries. American Geographical Society of New York Records, 1723-2010, bulk 1854-2000. AGSNY AC 1, Box 187, Folder 5. https://collections.lib.uwm. edu/digital/collection/agsny/id/38481/rec/450

Bowman, I. 1921: The new world: problems in political geography. - World Book Company, Yonkers-onHudson. 632 p.

Bowman, I. 1930: Isaiah Bowman levele Alan G. Ogilvie-nek, 1930. január 25. - American Geographical Society Library. University of Wisconsin-Milwaukee Libraries. American Geographical Society of New York Records, 1723-2010, bulk 1854-2000. AGSNY AC 1, Box 187, Folder 6. https://collections.lib.uwm. edu/digital/collection/agsny/id/36655

CholnoKy J. 1998: Önéletrajz. - Vár ucca tizenhét 6. pp. 185-339.

DHAnd, O. 2018: The idea of Central Europe: Geopolitics, culture and regional identity. - I. B. Tauris, London. $288 \mathrm{p}$.

Dunbar, G. (szerk.) 2001: Geography: Discipline, profession and subject since 1870. - Kluwer, Dordrecht. 336 p.

FEST A. 1922: Egy angol geográfus Magyarország feldarabolásáról. - Földrajzi Közlemények 50. pp. 177-180.

Fodor F. 2016: Ellettörténet. - In. GyőRI R.- JoBBITT, S. (szerk.): Fodor Ferenc önéletírásai. ELTE Eötvös József Collegium, Budapest. pp. 235-350.

GinsBurger, N. 2016: Academic networks and scholarly circulation between wars and peace (1912-1919). The expertise of Jovan Cvijić and his colleague geographers through the cases of Trieste and Fiume. - Cybergeo, document 784. doi: 10.4000/cybergeo. 27690.

GLANT T. 2020: Az Inquiry, az amerikai béke-előkészületek és Magyarország sorsa, 1917-1918. - In. GLANT T. (szerk.): Az Egyesült Államok útja Trianonhoz. Az Inquiry és Magyarország jövője, 1917-1918. (Források.) Bölcsészettudományi Kutatóközpont, Történettudományi Intézet, Budapest. pp. 9-48.

HEFFERnAN, M. 1996: Geography, cartography and military intelligence: The Royal Geographical Society and the First World War. - Transactions of the Institute of British Geographers 21. pp. 504-533.

Hinks, A. 1915: Arthur Hinks levele John Scott Keltie-nek, 1915. szeptember 10. - RGS-IBG Archives, CB8.

Hinks, A. 1918: The Need for Pooling the Geographical Information at the Disposal of the Government RGS-IBG Archives, CB8.

Hinks, A. 1919: Arthur Hinks levele Walter Coote Hedley-nek, 1919. január 8. - RGS-IBG Archives, CB8.

Holdich, T.-LYdE, L. 1915: The geography of the war: Discussion. - The Geographical Journal 45. pp. 13-15.

HoLdiCH, T. 1916: Political frontiers and boundary making. - Macmillan. London. 307 p.

Holdich, T. 1918: Boundaries in Europe and the Near East. - Macmillan. London. 224 p.

JESZENSZKY G. 1986: Az elveszett presztízs. Magyarország megítélésének megváltozása Nagy-Britanniában (1894-1918). - Magvető Könyvkiadó, Budapest. 368 p.

JESZENSZKY G. 2019: A brit külpolitika útja Ausztria-Magyarország felbomlasztásához-Századok 153.pp. 5-40.

Johnson, D. 2020: Douglas W. Johnson levele Isaiah Bowmannek, 1918. május 9. - In. GLANT T. (szerk.): Az Egyesült Államok útja Trianonhoz. Az Inquiry és Magyarország jövője, 1917-1918. (Források.) Bölcsészettudományi Kutatóközpont, Történettudományi Intézet, Budapest. pp. 199-206.

KeARns, G. 2009: Geopolitics and empire: The legacy of Halford Mackinder. - Oxford University Press, Oxford. 320 p.

Kogutowicz K. 1919: Angol vélemény a győzelmi mámor előtt. - Földrajzi Közlemények 50. pp. 41-45.

LABBÉ, M. 2018: Eugene Romer's 1916 Atlas of Poland: creating a new nation state. - Imago Mundi, 70.pp. 94-113.

LANSING, R. 1921: The peace negotiations: a personal narrative. - Houghton Mifflin, Boston and New York. 328 p.

LYDE, L.-MOCKLER-FERRYMAN, A.F. 1905: A military geography of the Balkan peninsula. - Adam and Charles Black, London. 203 p.

LydE, L. 1915: Some frontiers of to-morrow: An aspiration for Europe. - A. \& C. Black, London. 120 p.

Lyde, L.-Trotter, H.-Fairgrieve, H.-Nichols, S.-Maudslay, W.-Wallis, B. 1916: Distribution of nationalities in Hungary: A discussion. - The Geographical Journal 47. pp. 187-188. 
LydE, L. 1921: The international rivers of Europe. - In. Report of the Eighty-Seventh Meeting of the British Association for the Advancement of Science. John Murray, London. pp. 213-220.

LyONS, H. G. 1915: The importance of geographical research. - The Geographical Journal 46. pp. $254-269$.

Mackinder, H. 1919: Democratic ideals and reality: A study in the politics of reconstruction. - Constable, London. 272 p.

Macmillan, M. 2001: Peacemakers: the Paris Peace Conference of 1919 and its attempt to end war. - John Murray, London. 574 p.

Martin, G. 2015: American geography and geographers: Toward geographical science. - Oxford University Press, Oxford. 1240 p.

McFarlane, J. 1915: Geography at the British Association. - The Geographical Journal 46. pp. 374-380.

McFarlane, J. 1920: The reconstruction of Europe. - Scottish Geographical Magazine 36. pp. $217-232$.

n. n. 1918: The geographical bearings of the armistice terms. - Scottish Geographical Magazine 34.pp. 441-448.

n. n. 1920: Geography at the Congress of Paris, 1919. - The Geographical Journal 55. pp. 309-312.

Naval Intelligence Department 1919: The peoples of Austria-Hungary. I. Hungary. Atlas. - H. M. Government, London. 144 p.

Newbigin, M. 1915a: Geographical aspects of Balkan problems. - John Constable, London. 243 p.

Newbigin, M. 1915b: The Balkan peninsula: its peoples and its problems. - Scottish Geographical Magazine 31. pp. 281-303.

Newbigin, M. 1917: Race and nationality. - The Geographical Journal 50. pp. 313-328.

Newbigin, M. 1921: Some geographical aspects of nationality and internationalism. - In. Report of the EightySeventh Meeting of the British Association for the Advancement of Science. John Murray, London. p. 224.

NewBigin, M. 1922b: Human geography: First principles and some applications. - Scottish Geographical Magazine 38. pp. 209-221.

Newbigin, M. 1923: Human geography: First principles and some applications. - In. Report of the Ninetieth Meeting of the British Association for the Advancement of Science. John Murray, London. pp. 94-105.

NiCOLSON, H. 1933: Peacemaking 1919. - Constable, London. 378 p.

OgILVIE, A. 1915a: Cartographic needs of physical geography. - The Geographical Journal 45. pp. 46-61.

OGILvie, A. 1915b: Alan G. Ogilvie levele Dunnington Jeffersonnak, dátum nélkül, valószínúleg 1915. július. - Ogilvie Papers, University of Edinburgh Collections, Centre for Research Collections, E2010.39.

Ogilvie, A. 1916: Report on the Work of the Printing Section, R.E. from January to December 1916. - Ogilvie Papers, University of Edinburgh Collections.

OGILvIE, A. 1919: Alan G. Ogilvie levele Arthur Hinksnek, 1919. április 2. - RGS-IBG Archives, CB8.

OGILVIE, A. 1920: A contribution to the geography of Macedonia. - The Geographical Journal 55. pp. 1-30.

OGILVIE, A. 1921: Physiography and settlement in southern Macedonia. - Geographical Review 11.pp. $172-197$.

OGilvie, A. 1922: Some aspects of boundary settlement at the Peace Conference. - Society for Promoting Christian Knowledge, London. 34 p.

OGILVIE, A. 1924: Modern geography as a study and as an aid. - Scottish Geographical Magazine 40. pp. 65-74.

OGilvie, A. é.n.: Diaries - University of Edinburgh Collections, Centre for Research Collections, E2010.39.

OGILvie, E. é.n.: Diaries - University of Edinburgh Collections, Centre for Research Collections, E2010.39.

PALSKY, G. 2002: Emmanuel de Martonne and the ethnographical cartography of central Europe (1917-1920). - Imago Mundi 54. pp. 111-119.

PARKER, W. H. 1982: Mackinder: Geography as an aid to statecraft. - Clarendon, Oxford. 304 p.

SEEGEL, S. 2018: Map men: Transnational lives and deaths of geographers in the making of East Central Europe. - University of Chicago Press, Chicago. 320 p.

Smith, N. 2003: American empire: Roosevelt's geographer and the prelude to globalization. -University of California Press, Berkeley. 592 p.

TeleKi P. 1922: Newbigin, Marion, J., D. Sc.: Geographical Aspects of Balkan Problems in their relation to the great European war. (Recenzió) - Földrajzi Közlemények 50. pp. 199-200.

Temperley, H. 1920: A history of the Peace Conference of Paris. I-VI. - Hodder and Stoughton, London.

Tooze, A. 2014: The deluge: The Great War and the remaking of global order. - Penguin, London. 672 p.

WALLIS, B. 1911: The use of statistics in the teaching of geography. - The Geographical Teacher 6. pp. $107-114$.

WALLIS, B. 1916: Distribution of nationalities in Hungary. - The Geographical Journal 47. pp. 177-187.

WALLIS, B. 1917: Peoples of Hungary: Their work on the Land. -Geographical Review 4. pp. 465-481.

Withers, C. 2010a: Geography and Science in Britain 1831-1939: A Study of the British Association for the Advancement of Science. - Manchester University Press, Manchester. 280 p.

Withers, C. 2010b: Alan Grant Ogilvie (1887-1954). - Geographers Biobibliographical Studies 29. pp. 1-34. Withers, C.-Finnegan, D.-HiggitT, R. 2006: Geography's other histories? Geography and science in the British Association for the Advancement of Science, 1831-c.1933. - Transactions of the Institute of British Geographers 31. pp. 433-451. 